\title{
Systemic Propaganda as Ideology and Productive Exchange
}

\author{
Gerald Sussman
}

School of Urban Studies and Planning, Portland State University, sussmang@pdx.edu, http://www.pdx.edu/usp/profile/meet-professor-gerald-sussman

\begin{abstract}
Informed by the works of Marx and his progeny (Lukács, Gramsci, Althusser) as well as more recent marxian scholarship, the purpose of this paper is to explore the role of ideology and propaganda in the production and circulation of commodities and in the informalization of the contemporary workplace, particularly in the context of the promotional economy, politics, and culture of the United States. The heightened functions of media and communication technologies mark the pinnacle expression of late capitalism - the production, reproduction and colonization of the sphere of consciousness as a necessary condition for the maintenance of the corporate state as it faces its most profound contradictions in production and governance. The central question is whether the present dialectic is leading to a more liberated commons or to a society of exploited prosumers in what Italian Autonomistas call the "social factory"
\end{abstract}

Keywords: Marxism, Ideology, Propaganda, Prosumer, Labor

Acknowledgement: The author wishes to express his thanks to Sy Adler and Evguenia Davidova, who read and provided useful critiques on a draft of this paper.

\section{Introduction}

"The more production comes to rest on exchange value, hence on exchange, the more important do the physical conditions of exchange - the means of communication and transport - become for the costs of circulation. Capital by its nature drives beyond every spatial barrier. Thus the creation of the physical conditions of exchange - of the means of communication and transport - the annihilation of space by time - becomes an extraordinary necessity for it" - Karl Marx (1973, italics added)

"We Are All Workers" - Levi's ad

As a living praxis, one of the critical tasks of marxism ${ }^{1}$ is to apply its incisive logic to interpreting the current conditions in the labor process and in the modern production of surplus value. Reflecting on the influence of capitalist state power and ideology on popular consciousness and on labor resistance, this essay argues that marxist media studies is a tool not only for understanding communications as an infrastructure of capitalist production but also in explaining its increasingly penetrative applications as systemic propaganda. Media are centrally important in reproducing the ideological preconditions underpinning state legitimacy at home and abroad and, a fatal contradiction, in deepening the abstraction, alienation, and dehumanization of labor, ultimately destroying the very basis of its legitimacy. The accumulation, coercion, and cultural functions of mainstream media in support of the capitalist mode of production - within what has become a promotional economy - have intensified and yet are increasingly transparent, making hegemonic (i.e., ruling class) ideology, the grand narrative behind propaganda, considerably more vulnerable to challenge and disruption. If anything, the internationalization and automation of production enabled through digital technology has only strengthened the marxian approach to understanding the radical changes in capital accumulation and worklife (Dyer-Witheford 1999, 5-6).

In this essay, I look at formal marxist interpretations of ideology from four principal sources of that discussion, Marx \& Engels, Lukács, Gramsci, and Althusser, and apply their thinking to present day revisionist marxian analyses of labor to build on the critical intersection of the two. I argue that

\footnotetext{
${ }^{1}$ I use the lower case for marxism, marxist, and marxian to assert its assimilation as a worldwide framework of analysis, equivalent to putting capitalism and socialism in lower case.
} 
the neoliberal transformation of the economic system, with particular focus on the United States, from one based on manufacturing employment (now down to below 10 percent from 16.5 percent in 1987 and an even starker decline in its share of GDP: 11 percent in 2010 from 25 percent in the early 1980s) to one built on services, including financial and information services, has altered the political and ideological culture. In this context, promotion and ideology-based propaganda ${ }^{2}$ have risen to central factors of production - while directly influencing the casualization, informalization, and precarity of labor.

This essay draws in part on the work of the Italian Autonomistas and their "social factory" thesis in which distinctions between formal and informal labor and producer and consumer continue to break down ${ }^{3}$. To this I add the importance and organic role of systemic propaganda in reducing the status of citizens to individuated consumers and of citizenship to spectatorship. I start with core ideas regarding base and superstructure to set up the marxian framework and proceed to a general discussion of the uses of propaganda in the contemporary production process, the neoliberal economic context, ideology and class consciousness, and the relationship of ideology and propaganda to the informalization of labor in the social factory.

\section{Propaganda and Ideology as Base and Superstructure}

In his Preface to A Contribution to a Critique of Political Economy (1859), Marx distinguished the realm of the social relations of production (the base) from that of the ideological (legitimating) institutions (the superstructure) that help to maintain the political order:

In studying such transformations [leading to revolution] it is always necessary to distinguish between the material transformation of the economic conditions of production, which can be determined with the precision of natural science, and the legal, political, religious, artistic or philosophic - in short, ideological forms in which men become conscious of this conflict and fight it out.

That men (sic) would fight it out makes clear that what Marx had in mind about ideology is that while it is dominated by the institutions of capital, it is nonetheless contested terrain over which conflict continuously resurfaces, and not simply a predictable sphere predetermined by virtue of the control of the productive forces.

However, capital is never complacent about the risks associated with ideology. In its relentless and ever-expanding drive toward totalizing power over people and non-human resources and over time and space, late capitalism has mapped out consciousness as its final frontier. This involves a deeper order of production and continuous reproduction of ideology and public persuasion necessitated by the service character of the digital economy and aimed at cultivating passivity, the promotion of desire, and the construction of materialist identities. What do I mean by propaganda? To begin with, propaganda refers to organized doctrinal texts communicated throughout the voice, print, and audio/visual media in the service of state and corporate interests (and of aspiring power interests). Systemic propaganda means the penetration of promotional activities into almost every sphere of public life: the conduct of domestic politics and foreign affairs, the selling of public policy, the marketing of goods, services, and public and private institutions, the profusion of consumption within the "culture-ideology of consumerism" (Sklair 2001), with social psychological inducements to self-commodification (adoption of the insignia, habits, and discursive practices of the commodity culture) and an informalized "prosumer" labor force. It is also found in the wholesale infomercialization of news and spectacularization of mass media, joined by intensified subterranean and sublimi-

\footnotetext{
2 The general distinction I make between promotion and propaganda is that promotional activities are individuated acts on behalf of specific products and policies, whereas propaganda (which incorporates promotion) is undertaken for the broader purpose of constructing ideological hegemony over the whole society. On the distinction between ideology and propaganda, the former is a world view (a way of making sense), while the latter is a set of discursive and symbolic practices derived from a particular form of ideological sense-making.

${ }^{3}$ There is an intensive debate about whether the Automistas are indeed marxists. That debate is beyond the scope of this paper. I wish only to infer that what constitutes labor has changed with the intensification of capitalist relations of production within the digital informational mode of development and the relocation of production from the factory to the social factory.
} 
nal advertising, the commercialization of public space and public events, and in the promotion of self-promotion (via websites, Facebook, blogs,Twitter, etc.). The range and depth of promotion throughout the cultural and political life of the United States and other countries has led to what a group of critical scholars have termed a "propaganda society" (see Sussman 2011). By promotion I mean a lower-level regular employment of advertising, marketing, direct marketing, public relations $(P R)$, and other direct selling initiatives on behalf of the more prosaic objectives of both elites and non-elites and performed by those trained as active promotional and self-promotional agents.

On the question of ideology, I first turn to Marx \& Engels. In The German Ideology, they start with the universal structure of the commodity, which is the material embodiment of the social relations of production reified within capitalist ideology as a relationship not among workers but among things. The reification takes the form of what Marx (1967) referred to as the "commodity fetish", the objectification of the commodity dwelling on the outward appeal of a thing without reference to the intrinsic exploitative conditions of labor and unpaid "externalities" that brought such a thing into existence and the circuit of exchange. Representations of an independent character of commodities, orphaned from their direct producers, are thus made to appear natural. The "superstructure" is a realm of consciousness-molding (ideology), a range of activities produced by institutions (e.g., education, church, media, courts, corporate self-promotion) acting as the legitimating, sometimes oppositional, agents of/against the capitalist "base" (sphere of production) to provide a culture of compliance with (or resistance to) the hegemonic designs and values of the ruling class.

Where does the marxist concept of ideology fit into an explanation of contemporary societal conditions? Marx and Engels clearly understood the power of ideology to indoctrinate the working class and to redirect their attention from the system of exploitation:

Morality, religion, metaphysics, all the rest of ideology and their corresponding forms of consciousness, thus no longer retain the semblance of independence. They have no history, no development; but men, developing their material production and their material intercourse, alter, along with this their real existence, their thinking and the products of their thinking.... generally speaking, the ideas of those who lack the means of mental production are subject to it. The ruling ideas are nothing more than the ideal expression of the dominant material relationships, the dominant material relationships grasped as ideas (Marx and Engels 1845).

For Marx \& Engels (1845), "language is practical consciousness", and we can interpret "language" to cover a broad swath of communication(s), including advertising and marketing, in the reproduction of hegemonic ideology and the materialist realm from which it springs. In the material universe that Marx inhabited, his emphasis was understandably placed on the central importance of communications as an infrastructure of capitalist production inasmuch as communications was confined to servicing the production and circulation of basic necessities of nineteenth century life. The hegemonic power (cf Gramsci) of ideological state apparatuses (cf Althusser) in his era was at an early phase of the emerging consciousness industries (cf Enzensberger). Marx died before the takeoff of the modern advertising agency and the onset of mass marketing that eventually established consumerism as a dominant way of life and as one that supervised a more efficient circuit of production-consumption. The velocity of circulation in the late nineteenth century could not compare to the contemporary speed with which capital, especially finance and other immaterial forms of capital (advertising, fashion, cultural activities, software, data files, works of art, photography, and the like), are moved around the world". "Brand value" is an immaterial form of value creation - the socialization of capital - in which consumers identify with the (fetishized) lifestyle ideas associated with the commodity (Arvidsson 2005). As Hardt and Negri $(2000,24)$ noted: "Biopower... refers to a situation in which what is directly at stake in power is the production and reproduction of life itself."

Marx generally regarded ideology as a construct of dominant repressive regimes, writing in The German Ideology (1845) the familiar epigraph, "The ideas of the ruling class are in every epoch the

\footnotetext{
${ }^{4}$ By 2010 , the volume of daily currency trading worldwide reached $\$ 4$ trillion (Watts 2010).
} 
ruling ideas...," expressing the interests and dominant material relationships of the state, whereas his intellectual progeny have tended to view ideology as a necessary function of any state, capitalist, theocratic, or socialist. Indeed, within the Soviet Union, the uses of agitation and propaganda (agitprop) were regarded as means to educate the masses about socialism and to animate and activate them in the pursuit of social rectification. Marx, however, primarily regarded ideology as the means by which the interests and dominant material relationships of the capitalist state and a mythical understanding of capital are naturalized in public consciousness, a theme critically elucidated by Antonio Gramsci.

Marx thus associated "ideology" with the false consciousness spread by the ruling class, a superstructural project intended to enjoin the obedience of the working class (the function of legitimation). For that reason, Marx devoted little attention to ideology as an alternative form of consciousness that could prepare workers to embrace socialism, though he did describe the moment in the class struggle when the proletariat turn from a class "in itself" (an sich) to a class "for itself" (für sich) (Marx 1971). For Gramsci, the domination of classes (hegemony) ${ }^{5}$ in capitalist societies is more ideological and cultural than physically coercive. The task of working class liberation, he argued, rests with educated radicals, the organic intellectuals (members of the working class who articulate a practical understanding of repression and struggle through active counter-ideology) capable of seeing through the miasma of bourgeois propaganda.

Althusser as well regarded ideology in dialectical terms and treated it as a formative aspect of class identity, though he attributed its power more in structural terms (infra). For Althusser, ideology establishes ways of thinking and acting. As he observed:

the reproduction of labour power requires not only a reproduction of its skills, but also, at the same time, a reproduction of its submission to the rules of the established order, i.e. a reproduction of submission to the ruling ideology for the workers, and a reproduction of the ability to manipulate the ruling ideology correctly for the agents of exploitation and repression, so that they, too, will provide for the domination of the ruling class "in words" (Althusser 1994, 104).

Althusser argued that under capitalism it is principally the education system that reproduces the culture of compliance; in an earlier era, the Middle Ages, it was the Church. These days the dominant (mainstream) media perhaps exercise even greater hegemony over the minds of working people than do formal educational institutions, a point made by the Frankfurt School theorists, particularly Herbert Marcuse (1964), who regarded media-driven consumerism as a totalitarian ideology for pacifying the working class. As a practice, propaganda relies on ideological understandings to effect its intended results.

In the workplace, ideology operates at each stage of production. Workers must be prepared to lend their power to the production process. They must also internalize the discipline in the workplace needed for its smooth operation. Ideology next assumes a critical function in the circulation of commodities (the role of advertising, marketing, branding, and other promotional activities are critical here). And finally ideology is central to the conversion of commodities at the point of sale where they are transformed into money for sellers and into consumption for buyers (Kjøsen 2010). In the production of digital commodities, the points of production and consumption are nearly coterminous, annihilating space by time and permitting capital to rapidly increase the velocity of circulation and the entire circuit of production-consumption.

Raymond Williams (1973), however, argued that ideology should not be construed as merely instrumentalist or reductionist:

\footnotetext{
${ }^{5}$ The hegemonic culture is one in which the values of the bourgeoisie become the "common sense"' values of the whole society, where the working class identifies its own interests with that of the bourgeoisie and thereby desist from resistance or rebellion.
} 
For if ideology were merely some abstract imposed notion, if our social and political and cultural ideas and assumptions and habits were merely the result of specific manipulation, of a kind of overt training which might be simply ended or withdrawn, then the society would be very much easier to move and to change than in practice it has ever been or is.

Rather, ideology is constructed through interplay between base and superstructure, between culture, including its residues of earlier cultural epochs, and the reflexive practices of cultural, social, and political economic institutions. Capitalist ideological reproduction is achieved not through the repression of dissent as much as its appropriation within commodified confines of protest, stripped of spontaneous or revolutionary impulses. Capital takes no prisoners in its assault on all manifestations of cultural resistance ${ }^{6}$. In one of the more explicit consumerist efforts to wipe out memories of revolutionary thought, Macy's logo, a five-pointed red star, 60 years ago would have brought its executives before the House Un-American Activities Committee. Saks Fifth Avenue uses designs that are stylized in the form of Constructivist state-run department store ads in the 1920s Soviet Union (Wilson 2009). Ads for Fortune 500 company Levi Strauss, produced by the Wieden \& Kennedy PR firm, sell jeans with such slogans as: "We Are All Workers", "Made Strong for the New Work", and "Everybody's Work is Equally Important". It wasn't a quote from Marx, when an ad called "2011 Jeep Grand Cherokee Manifesto Commercial" (Brian 2010) ran with the slogan, "Things We Make, Make Us", but it sounds as if it were.

Capitalism repeatedly draws on revolutionaries for its self-aggrandizing inspirations, a tribute of sorts to the irrepressible character of radical leaders and working people. But it repackages and commodifies radical movements without any reference to the original sources or contexts. True radical ideas and representations are never patented, but once stolen by capital they are converted to property. Perhaps even sections of the Communist Manifesto may one day be copyrighted, with infringement suits directed at anyone who dares to publicly recite its passages-similar to Time Warner's ownership of the ubiquitous happy birthday song.

In the digital informational era, the promotional (circulation) aspects of production take on a higher order of importance, a centrality of discursive and symbolic persuasiveness and general valorizing and non-valorizing social practice, inasmuch as the manufacturing base has been relocated en masse to low wage (third world) industrial zones of the new international division of labor. This leaves Western economies the task of selling and consuming the commodities produced offshore. In the United States, where shopping has long been the most important personal activity outside of work and sleep, circulation has become the most critical aspect of wealth creation - the circulation of that which is affectively produced in the first place (in effect the circulation of circulation) - and within that reality immaterial promotion efforts are key to the maintenance of the capitalist mode of production, the overarching ideological sphere, and the unending waging of class warfare and pursuit of cultural hegemony over workers, wherever they may cluster.

\section{Propaganda and the Mode of Production}

Where does contemporary commercial ideology fit into Marx's superstructure thesis? In the $19^{\text {th }}$ century, communications came into its own as a means of supporting industrialization, urbanization, and mediatization of the leading industrial cities and states. Marx was among the most prescient observers of the power of communications to speed up the process of commodity production

\footnotetext{
${ }^{6}$ Among the many examples of such appropriation of dissent are: the fashion of "convict" pants; clothing bearing names like Ideology, Propaganda, and Revolution; Das Kapital and Che Guevara t-shirts; "The Body Shop" capitalizing on the ideology of the environmental movement; Mercedes Benz car ads ripping off the eponymous song title lyrics of Janis Joplin; corporate polluters greenwashing themselves (to which culture jammers like Adbusters retaliate); the PR industry's "astroturfing" and "guerrilla marketing"; corporate tycoons assuming the pose of global philanthropists; Apple Computer marketing its identity as rebellious, even while it brutally exploits its workers in China to the point of inciting active rebellion (Harris 2012).
} 
and circulation and in the spreading profanity of a capitalist ideology that, as he and Engels put it, "batters down all Chinese walls" (Marx and Engels 1848). For the most part, however, Marx looked at communications, most especially the telegraph, as an instrument serving the production sphere - in contrast to the dominant ideology then and now that construes technological history within traditional hagiographic renderings of Morse, Bell, Edison, and others and a genealogy of their "inventions" (see Sussman 1997, especially chapters 3 and 4.) With the advancement of communications in commerce ${ }^{7}$ (the facilitating role of telegraphy in newspapers, newspapers in radio, radio in television, and the like), later marxists such as Gramsci and Lukács took a deeper interest in and appreciation of the ideological functions of communications.

Since the Second World War, the state increasingly has exercised ideological control over the accumulation, coercion, and legitimation processes with the aid of advanced technology and the sweeping presence of (pace Althusser) Repressive State Apparatuses and the less blunt instruments of Ideological State Apparatuses. State legitimacy rests in part on its capacity to represent and internalize in the consciousness of its citizens its raison d'etre and its policies and manner of administration as natural, just, and in the best interests of the populace. Ideology is stored propaganda (and vice versa), employed toward specific state and commercial objectives and ratified through the general beliefs, values, assumptions, and received ideas that propagate its cultural power. In the sphere of material culture, propaganda is central to the production of commodities, in the manufacture of desire (without use value there is no exchange value), and in the broader ideology of consumption as a way of life (consumo, ergo sum).

As Mike Wayne suggests, to update Marx we need not only to consider formal marxist categories of analysis but to review them in light of a changed world that takes into consideration the "increasing importance of culture, communication, the exchange of ideas, feedback systems, data analysis and so forth, in the production process" $(2003,45)$. In a promotional economy, the forces of production are dedicated to circulating domestically- or foreign-made products and requires a system of surveillance and information processing to fuel its steady stream of propaganda. It also involves a systematic violation of norms of privacy of millions of people on whose lives it relies for its data harvesting and valorization - constituting in effect an "identity labor" force. This panoptic power in turn rests on a heightened fetishizing of commodity culture that induces workers and consumers (and intermediary "prosumers" - see infra) to submit not just their knowledge but their personal profiles to the labor process and commodity value formation.

In his widely cited discussion of audience as labor, Dallas Smythe $(1977,1981)$ anticipated a future in which sections of capital would deepen the range of its efforts toward the commodification of consciousness and a closer reliance on the value-producing consumer (prosumer). Smythe focused on advertising and the "work" of audiences, which he understood to be a demographic, in the watching of ads. Thus the audience, acting as a "labor force," a deviation from the orthodox marxist view of surplus value creation (what he saw as a "blindspot" in its communication research), is itself treated as a commodity. But what he did not live long enough to witness were the advanced scientific methods by which advertisers watch the watchers. His most important insight was that promotion breaks down the separation between producers and consumers, between work and leisure, and between use value and exchange value. Advertisers pay for audiences' TV and print media watching (or radio listening) time to sell them not only specific commodities but also the habit of consumption, and they are happy to pay for audiences' attention, particularly those audiences with the propensity to consume their products ${ }^{8}$.

Corporate ideology reifies and universalizes false consciousness by concealing the exploitative nature of the commodity, as if it were something other than the labor and labor conditions embedded in its materialization, and through identification with possession of those commodities ( 1 am what I own). In this way the object becomes the subject, and the subject becomes the object. In-

\footnotetext{
${ }^{7}$ Telegraphy was also crucial in the development of financial markets and in consolidating the power of Wall Street over national capital.

${ }^{8}$ To this far-sighted analysis, Jhally and Livant (1986) offered the more nuanced explanation of the co-production of "watching time" by networks that purchase the "watching power" of audiences and sell it to advertisers.
} 
deed, capitalism could not operate without attending to the molding of what Lukács called a "unified structure of consciousness" amongst the workforce - as producers (engaged in exchange value), as consumers (engaged in use value), and as administrators of the system of production. "Bureaucracy implies the adjustment of one's way of life, mode of work and hence of consciousness to the general socioeconomic premises of the capitalist economy" (Lukács 1971).

The propaganda and promotional functions of the state, particularly when the success of the economy depends on the sales effort, have never been more critical to its survival. Apostles of neoliberal doctrine, particularly in the United States, seek to bring the remainder of nature and independent social life into the circuit of production and consumption through a revised international division of labor, segregating the manual from mental and creative from robotic aspects of work. As U.S. manufacturing industries and agriculture have been shrinking, services have come to represent more than 80 percent of GDP, with information services representing the largest share of value added GDP and 59 percent of the U.S. workforce by 2000 (Apte, Karmarkar and Nath 2007, 2, 4). The promotional activities, including advertising, marketing, public relations, branding, and sales management are crucial to the circulative aspects of production in the U.S. economy, which, with only 4 percent of the world population consumes a quarter of global energy output and a third of the world's paper and plastic; the average American as of 2000 consumed 53 times more than the average Chinese person (Tilford 2000) though that ratio is certainly changing with China's developing consumer economy.

Both the growth and concentration of the U.S. promotional economy is astounding. Just 100 advertisers (of nearly 40,000 firms) represent 41 percent of the country's total advertising expenditures (Wood 2008). Advertising alone was an estimated 2.6 percent of GDP in 2007 or $\$ 153.7$ billion (TNS Media Intelligence 2007), while worldwide spending on advertising reached close to $\$ 500$ billion in 2008 (Mullaney 2009). And although advertising momentarily slowed during the start of the recession, 2008-2009, PR has continued to expand. Total U.S. spending on communications in 2008 was estimated at $\$ 923.91$ billion, a 5.4 percent growth over the previous year (IT Facts 2008). This staggering figure is close to Australia's entire GDP and larger than all but 13 (out of 210) other countries. The infrastructure for propaganda and promotion has never been more permeative.

The promotional culture reaches into all phases of political, economic and social life. The phrase "public space" is fast losing its meaning, as one is confronted by a visual spectrum in American cities that are filled with advertising and commercial logos. High school stadiums bear the imprint of commercial advertising, while soft drink companies compete for school "pouring rights." Street car and bus stops are branded with corporate identities as are professional sports stadia and even theater tickets. Probably as many people watch the Super Bowl for its 30-second ads, each of which in 2012 cost on average $\$ 3.5$ million, as those interested in the game itself ${ }^{9}$. Personal websites, blogs, and Facebook accounts and e-book readers come with conspicuous commercial advertising. With the help of a compliant Supreme Court, which in 2010 ruled in favor of permitting nearly unlimited spending by "super PACs" (Citizens United v. Federal Election Commission), American federal elections are expected to cost over $\$ 8$ billion in 2012. Most of this spending will end up as 30-second TV political spots, for which political media consultants will collect a 15 percent commission. (For a longer discussion of corporate branding, see Sussman 2011.)

\section{Neoliberalism, Ideology, and the Informalization of Living Labor}

Traditional propaganda normally was employed in the service of specific policy or project outcomes of the state; systemic propaganda derives from a generalized and globally integrated strategy of development rooted in neoliberal political economy and supportive technological infrastructure.

\footnotetext{
${ }^{9}$ The amount of actual ball-in-play time for an average 185-minute televised National Football League game comes to just 11 minutes; the rest is advertising (a third), replays, huddling, and just shots of players standing around. (Biderman 2010). This calculation of TV advertising time doesn't include the visual space covered by corporate logos adorning player uniforms and stadium billboards, fences, green screens, and merchandise.
} 
One can date the transition to systemic propaganda to the beginning of "deindustrialization," regulation, and flexible accumulation, starting in the 1970s. Aided by digital communications technology, boundaries, economic and moral, public and private, that long stood intact to that point began to crumble like the Berlin Wall. With the shift from fordism to a more flexible mode of production, capital is able to capture "larger pools of social and cultural knowledge" (Terranova 2000,38), which it transforms into commodities and private wealth. Despite the severe crisis of the 1970s, capitalism was anything but finished and was not about to yield to a crisis of confidence, a legitimation crisis - what Jimmy Carter sermonized at the time as a national "malaise". The neoliberal project acquired a political leadership with Reagan and Thatcher that reinvigorated capitalist expansionism. Althusser (1994) argued, however, that the capitalist state does not depend for its vitality on innovations in the technological sphere or on particular individuals but does require a recharging of its ideological channels: "To my knowledge, no class can hold State power over a long period without at the same time exercising its hegemony over and in the State Ideological Apparatuses" (italics in original, 112).

Indeed, with its grounding more firmly embedded in services than manufacturing and with greater emphasis on individuated consumption, neoliberalism is marked by increased investments in cultural production and in the proliferation of signs (Goldman 1992) that permeate every sphere of society. The selling of commodities, material and immaterial, is now intrinsic to the corporate capitalist state's mode of economic, political, and cultural (re)production, such that the consumerist life becomes the norm of a corporatist state society, making propagandists of those engaged in this collective effort to convert citizenship to spectatorship. The promotional (capitalist) economy is the most predatory of all forms of industrial economies, as it is designed to colonize not only the bodies of its workers, as in the manufacturing system, but also their consciousness, identity, and personality - as well as the leadership of the state. Well over half of the members of the U.S. Congress become lobbyists, lawyers, or executives of corporations once they formally leave their government posts, normalizing business practice as an extension of government service ${ }^{11}$.

In the promotional economy, the consciousness of the workforce is "atomized" for the segmented tasks of commodity production, through which workers become alienated from any sense of their independent productive capacities and further marginalized as remote appendages to machine production. The logic of such development and the resources employed for its implementation, including digital technology and objectified labor, are spread out over time and space. The relatively stable conditions of work that once existed vanish from mainstream public discussion, and the life of uncertainty, instability, and precarity becomes the general social norm. That is to say, within a specific mode of development ${ }^{12}$, all life is organized under a regime and discipline of understanding (ideology) and a division of labor assigned to the main tasks of that regime.

The transition from a fordist regime to what Harvey (2007) calls one of "flexible accumulation" necessitated a deeper level of worker discipline that could expand capitalist control over the spatially dispersed and disaggregated workplace. Time-motion methods of managing workers in the manufactory offered lessons for tertiary sector jobs, such that standardized, routinized, regimented, repetitive tasks could be instituted in service practices, in effect creating not a post-industrial as much as a hyperindustrial society (Sussman 2011, 11-12). Workers' subjectivity, seized and surveilled as serviceable in the production-consumption circuit, becomes the veritable property of capi-

\footnotetext{
${ }^{10}$ The term "deindustrialization" is somewhat contentious, depending on whether one views economy in national or global terms. If the latter, one can argue from a world systems perspective that manufacturing although spatially decentered remains centralized in terms of control, and that the overseas transnational corporate workforce is constituted as part of a common labor formation with the design, R\&D, promotional, and sales workers that are employed in the core countries.

${ }^{11}$ According to the Center for Responsive Politics (2012), of those members of the $111^{\text {th }}$ Congress (2009-2011), 52 percent went to become lobbyists or clients of lobbyists; an additional 5.2 percent worked for political action committees and 22.1 percent of the rest became executives of private organizations.

${ }^{12}$ Manuel Castells (1996) uses the term of "mode of development" to refer to the digital media of production and exchange. He regards the digital informational mode of development as akin to the centralizing force of electricity in the making of the industrial world a century earlier.
} 
tal. Informal identity labor is integrated with formal labor, with the predominant form of work rooted in informational services and the promotional industries.

Fordist (routinized) labor, meanwhile, is effectively expanded through the collapsing and convergence of job descriptions or expectations in which promotional performance is appended to jobs that in the past did not include them, such as the scripted speech of chain-store cashiers ("Did you find everything you were looking for?"), customer relations employees, technical support and other call-center operators, and wait staff who in their transactions with consumers suggest additional purchasing options ("Would you like a drink with that order?" and the like). Similarly, TV sportscasters and radio talk show hosts are now expected to plug products on-air. Promotional behavior under the new work requirements is intended to increase exchange value, thus enabling an intensification of exploitation (the surplus value appropriated and valorized under such ultra-commodified "labor power").

In the neoliberal promotional economy, with the infrastructural support of digital technology, capital has undergone a major restructuring, driven by both organizational and technological opportunities and necessities - and characterized by deregulation, privatization, deterritorialization, cutbacks in government social spending, technological and institutional convergences, union-busting, erosion of the public sphere, manufacturing and service sector outsourcing, and a deepening of consumerist ideology. When not long ago, one could still imagine the separation of the workplace and home life, work and leisure, public and private space, producer and consumer, formal and informal labor, today with corporate capital at the forefront of social and political changes, these and other such dichotomies are converged and subsumed under a corporate aegis. Before entering and after departing the formal workplace, workers routinely submit their identity data, through covert surveillance and institutionalized identity theft, but often through "voluntary" means as well, for the production and marketing of goods and services. In such surplus value-generating opportunities, "prosumers" are employed consciously or unconsciously as free informal labor, ${ }^{13}$ undertaking such labor using their own equipment and software (computers, programs, and internet connections). The intensification of labor extraction in a system in which informational aspects of production have become increasingly possible and necessary has led to a changing form and composition of labor in material and immaterial goods production ${ }^{14}$.

Creative industries also regularly announce, usually online, the outsourcing of problem-solving activities to amateurs or specialists willing to participate without standard pay, perhaps in hopes of a prize or status of some sort, in finding solutions that profit the company - a system of free or very modestly compensated labor the industry calls "crowdsourcing" 15 . Inasmuch as such work contributes to the creation of exchange value, people at large and outside the formal workplace have come to constitute a major source of informal labor (in the crowdsourcing example via the liberal use of their knowledge for software production). As one study noted, "the co-creation economy is about experimenting with new possibilities for value creation that are based on the expropriation of free cultural, technological, social, and affective labor of the consumer masses" (Zwick, Bonsu and Darmody 2008, 166). The principal form of labor involved in commercial crowdsourcing or surveil-

\footnotetext{
${ }^{13}$ One form of crowdsourcing is local television stations' use of their websites, blogs, Facebook, Twitter, YouTube, and special apps for soliciting news tips, photos, video, and feedback from prosumer audiences, in some cases on an exclusive (quasi-contractual) basis. Certain high-end cameras are marketed as "prosumer" quality.

${ }^{14}$ The formal workplace is not by any means the sole locus of value creation. There is in fact a presumption of free labor that now prevails in many spheres of daily life: self-checkout at shopping centers, submission to various kinds of polling and consumer surveys, consumer data profiling created through "cookies" and credit card surveillance, registration for the use of websites, the use of ATM machines instead of tellers, and many other, often inconspicuous, acts that convert consumer behaviors and information into factors of production, further mystifying (fetishizing) the nature of the commodity.

${ }^{15}$ The willingness of workers to supply their free intellectual labor to a private entrepreneur represents the power of reification of commodities disassociated from their social relations of production. Informal labor that contributes aesthetic, social, or affective appeal to commodities or that helps establish their marketable potential is in most instances free labor, not wage labor, sometimes offered voluntarily, more often captured by stealth. It demonstrates what Hardt and Negri (2001) have argued about the intensification of capital's internalized direction, though, I would contend, this does not mean that capital has abandoned its spatially aggrandizing ambitions.
} 
lance is promotional in character, reinforcing the appeal and ideological aspects of the consumerist economy. Businesses want to know how to better design, market, and brand their products and look to audiences for that knowledge.

Such new forms of labor, compelled by speedup in a promotional economy, one in which the space between production and circulation is potentially reduced to zero (Kjøsen 2010, 83), generates a greater reliance on mental over physical labor. This "immaterial labor", writes Tiziana Terranova, a critic from the Autonomista persuasion, "involves a series of activities that are not normally recognized as 'work' - in other words, the kinds of activities involved in defining and fixing cultural and artistic standards, fashions, tastes, consumer norms, and, more strategically, public opinion" (Terranova 2000, 41), but which are nonetheless part of the "process of valorization" (Lazzarato 1996, 132-133). That is to say, consumers help to produce the value of a commodity, even if only within a narrow range of resources that such labor is able or willing to invest in a given commodity creation ${ }^{16}$.

The traditional categorical boundaries between production and consumption have thus begun to wither. In a parallel manner, the distinction between traditional media products and advertising has also begun to disappear in the age of mega-media, the "infomercial", product placement, news plugola (the marketing of parent or affiliated network assets as part of the news agenda; see Higgins and Sussman 2007), and numerous other forms of commercial cross-over that shift the construction of commodities from direct and formal to more indirect and informal sources of production. As one critical technology scholar comments, "the direct exploitation of labour is becoming less important as a source of profit and the private exploitation of social knowledge is becoming more important" (Tessa Morris-Suzuki, cited in Arvidsson 2006, 9). Surveillance is also normalized at the level of popular media culture. The journalist Chris Hedges notes how 'Big Brother' and 'Survivor' glamorize the intrusiveness of the surveillance state" to draft voyeuristic impulses of audiences in the project of self-commodification (Hedges 2009, 39).

In the selling economy, greater importance is given to the circulation of commodities, which makes both its promotion and the larger culture of consumerism (ideology) central to the creation of surplus value. There is a separate sphere of activity, which can be called the production of consumption, involving the various promotional activities (advertising, marketing, public relations, sales management, branding, and the like), which are industries in and of themselves. The mobilization of people as prosumers in the promotional economy leads to what Mario Tronti (see Cleaver 1992) identified as the "social factory" - the production of all by all, a deeper level productive and ideological penetration integrating the social relations of production and consumption. Within the social factory, where capital focuses more of its attention on cultural production, the consumer imagines her/himself to have a communitarian identity through access to the commodity. Raymond Williams (1973), concerned with the prevailing ideology of capitalism, urged that "we should look not for the components of a product but for the conditions of a practice.... the point of departure, in practical and theoretical work, within an active and self-renewing Marxist cultural tradition."

Hyperindustrialization of work routines is typical in retail sales, telemarketing, automobile service, clerical jobs, and other low-wage, non-professional occupations, often organized with precise automated pavlovian signaling systems (e.g., buzzers and flashing lights in fast food restaurant kitchens, predictive dialing technology at call centers) that pace the responsive output of workers. Though there is now a more geographical spread of manual and mental labor, the conveyor belt method of production looks very much the same for the millions of workers tied to checkout counters, call centers, and fast food assembly lines, as it does in the manufactory setting. Even medical

\footnotetext{
${ }^{16}$ The Autonomistas, including Terranova, Lazzarato, Tronti, and others, are sometimes placed between orthodox marxists and anarchists, though they embrace notions of class in ways that anarchists do not. The principal difference between orthodox and autonomist marxism on the question of class is that the former take a broader view of what and who constitutes a class formation. In the context of a state where factory labor has greatly diminished in scale and where work is increasingly embedded in immaterial forms of production, it would appear appropriate to reconsider class constituency, although the concept of the social relations of production is as valid as ever.
} 
clinic physicians are paced by the clock and pressured to treat patients as processing units with taylorist regularity.

With new forms of immaterial capital and an informalized labor pool, there are no speed limits to the circulation of immaterial commodities. The reproduced value of commodities in digital format is potentially immense as there are no added production costs associated with each retransmission, hence superexploitation of those who produce but do not own the prototype. Capital in fact must withhold the release of digital commodities in order to prepare for its circulation (advertising, marketing, etc.) (Kjøsen 2010, 83). Once released, however, it is elatively easy for others to reproduce and recirculate items on a shareware basis. File sharing practices is known as "copyright infringement" from the capitalist standpoint, but could just as easily be regarded as redistribution of compensation in kind for the appropriation of labor value that went into the production of commodities better than access to software would be broader, more beneficial social benefits, such as single payer national healthcare, free higher education, and the guarantee of decent housing.

\section{All the King's Horses and All the King's Men Couldn't Put Humpty Together Again": The Coming Collapse of State Legitimacy?}

Under neoliberalism and the digital communications system, the consumer has become far more integrated not only as an end user of production (consumption) but as a factor of production - the prosumer. In the promotional economy in which surveillance and communications in general are now vital aspects in perfecting the circuit of production, from the sweatshops in China to the internetshops in America to final consumption, there are no longer well-defined boundaries to what constitutes labor (those who create exchange value). Far from undermining the marxist theory of value and the related precepts of exploitation and alienation, the idea of promotional labor places marxism at the center of understanding the new global economy. The biggest change in the past 35 years or so is the rise of the promotional economy in which the central economic (and cultural, political, and ideological) activity is selling, whether it be tangible commodities, largely produced offshore, or public policies.

With the system of production so entwined in the system of consumption, the ensemble of the "social factory," the present assignment of ownership of production knowledge to the capitalist class is fundamentally disputable. Value creation in the promotional economy makes conspicuous the fact that commodity production derives from socially constructed knowledge (Virno 2001) what Marx (1973) called the "general intellect." Capital relies on the general intellect to increase productivity and sustain its rate of profit. In the social factory, the scope of the general intellect on which capital can directly draw is vastly enlarged through the means of digital contact, surveillance, knowledge expropriation, and the promotion of desire. But, as Negri (2006), Žižek (2009), and others have argued, capitalism has privatized the general intellect, the result of which is an "increase of surplus labor time [that] prevents more and more people from enjoying the free time of creative learning and experimentation that would lead the general intellect to flourish" (Smith n.d., 5; italics in original).

The increasing use of informalized labor in the form of surveys, polling, crowdsourcing, focus groups, web use, media subscription, credit card surveillance, cookies, "cool-hunting," and myriad other ways of employing identity labor of consumers as value producers (prosumerism) makes virtually everyone a bonafide shareholder in the production of goods and services. That is, the capitalist system has converted the society as a whole into a production "factory" and into what has become a system of socially organized consumption (Lazzarato 1996), with labor functions extended throughout the matrix of personal, social, and work life. The system of patents, trademarks, and copyrights, always an ideological and legal as much as a property instrument for the control of production and regulation of society by the capitalist class, has become an anachronistic residue of a belief system that has no relationship to how production is actually constituted.

In a production system conceived as a reification of the "general intellect", the appropriate form of ownership would be collective. Of course the name given to a system in which ownership is as- 
signed to the whole society is socialism. Is socialism possible? In the promotional economy, it is all the more transparent that the working class as a whole ${ }^{17}$ produces the wealth of nations, ergo there has never been a more compelling justification for workers to claim political power on that basis. The creative designs of communications to manage capitalist society can also be employed and are being employed to undermine it (Wikileaks exposés, growing distrust of the mainstream media, media "piracy" and hacking, anti-advertising movements, growing uses of alternative media, Occupy social networking, and other on-the-ground and mediated forms of resistance). There are clear signs of rupture in US domestic ruling ideology, but physical conditions will have to deteriorate before a counter-ideology, based on collectivist thinking can take shape and produce propaganda in line with radically different notions of social progress, teleology, and the role of the individual.

What forms of opposition and resistance are presently feasible, and how can they rejuvenate a sense of class struggle? In a digital informational environment, mental labor is indeed difficult to keep proprietary, and there appears to be an unrelenting grassroots effort to maintain the principal information sharing and social networking system, the Internet, as a system of free exchange. No democratic state worthy of the name can exist without a vibrant communication system that provides citizens with the means to make informed and rational political and personal choices. There cannot be a complete negation of all that has evolved under capitalism, but there can be a reappropriation of the promotional means of production toward the cultivation of a harmonious work life, with far less emphasis on consumption and far more value placed on planetary coexistence with all life forms. It is important for social activists to fight for an open Internet system and at the same time for recovery of the airwaves. The Occupy Movement needs to include local and network TV channels as targets for occupation, because they still represent the principal sources of "news", information, propaganda, and ideology for most Americans. Their constant stream of misinformation, ideological distortion, and destructive consumerism and imperialist jingoism has been lethal to the prospects of a more democratic society.

An active and enlightened source of free exchange on the web, based on principles of inclusiveness and social justice, can contribute to a wakening and reawakening of the spirit of the commons and to deep challenges by the working class as a whole (the social factory) to state institutional repression and the fatuousness of its class-centered rationalizations. This level and consciousness of collective agency in turn can form the alternative of cooperative labor and the radical deconstruction of and reflexivity of refusal toward corporatism and the erosion of its hegemonic ideology and propaganda, the formation of socialist political institutions, and the gradual elimination of the many forms of exploitation and alienation and class reproduction itself. When the conditions are right, and with the aid of digital media designed for other promotional purposes, a tsunami of revolt, like that witnessed in the "Arab Spring", will spread across the shores of the United States and its corporate capitalist world system allies, cancelling the grand imperialist theft of worker knowledge and creativity and substituting collectivization for privatization in the common interest of citizenship and human survival.

\section{References}

Althusser, Louis 1994. Ideology and Ideological State Apparatuses (Notes Toward an Investigation). In Mapping Ideology, edited by Slavoj Žižek, 100-140. London: Verso.

\footnotetext{
${ }^{17}$ Hardt and Negri (2000) choose to refer to the class of non-capitalists as the "multitude", a somewhat vague description of the "99 percent"' Even if Marx's term "petty bourgeoisie" (those with capitalist administrative functions, such as lawyers, accountants, corporate scientists and engineers, and others) is out of fashion, his concept of class stratification is more substantial than the undifferentiated notion of "multitude." However, both Hardt and Negri and Marx use terminology, whether multitude or proletariat, that tend to wash over cultural and practical distinctions based on race, ethnicity, and gender.
} 
Apte, Uday M., Uday S. Karmarkar, and Hiranya K. Nath. 2007. Information Services in the US Economy: Value, Jobs and Management Implications. Accessed January 15, 2012.

http://www.ifm.eng.cam.ac.uk/ssme/references/Karmarkar_ref2_cambridgessme07.pdf

Arvidsson, Adam 2005. Brands: A Critical Perspective. Journal of Consumer Culture 5 (2): 235-258

Biderman, David. 2010. 11 Minutes of Action. Wall Street Journal, January 15. Online edition.

Brabham, Daren. 2011. The Myth of Amateur Crowds. Flow TV Website. January 15. Accessed January 15, 2012. http://flowtv.org/2011/01/the-myth-of-amateur-crowds/

Brian. 2010. In Want of Things We Can Touch. Anidea website. Accessed February 3, 2012. http://anidea.com/strategy/inwant-of-things-we-can-touch/

Castells, Manuel. 1996. The Rise of the Network Society: The Information Age: Economy, Society and Culture. Cambridge, MA: Blackwell.

Center for Responsive Politics. 2012. Revolving Door: Former Members of the $111^{\text {th }}$ Congress. Open Secrets.Org website. Accessed March 1, 2012. http://www.opensecrets.org/revolving/departing.php?cong=111

Cleaver, Harry. 1992. The Inversion of Class Perspective in Marxian Theory: From Valorisation to Self-Valorisation. In Essays on Open Marxism: Theory and Practice, Vol. 2, edited by Werner Bonefeld, Richard Gunn and Kosmos Psychopedis, 106-144. London: Pluto Press.

Dyer-Witheford, Nick 1999. Cyber-Marx: Cycles and Circuits of Struggle in High-Technology Capitalism. Urbana, IL: University of Illinois Press.

Fleming, Peter and Andrew Sturdy. 2011. "Being Yourself" in the Electronic Sweatshop: New Forms of Normative Control. Human Relations 64 (2): 177-200.

Goldman, Robert. 1992. Reading Ads Socially. New York: Routledge.

Hardt, Michael and Antonio Negri. 2000. Empire. Cambridge, MA: Harvard University Press.

Harris, Paul. 2012. Apple Hit by Boycott Call over Worker Abuses in China. The Observer, January 28. Online edition.

Harvey, David. 2007. A Brief History of Neoliberalism. New York: Oxford University Press.

Hedges, Chris. 2009. Empire of Illusion: The End of Literacy and the Triumph of Spectacle. New York: Nation Books.

Higgins, Carey L. and Gerald Sussman. 2007. Plugola: News for Profit, Entertainment, and Network Consolidation. In Urban Communication: Production, Text, Context, edited by Timothy A. Gibson and Mark Lowes, 141-162. Lanham, MD: Rowman \& Littlefield

IT Facts. 2008. Telecom Spending to Reach \$923.91 BIn in 2008. Accessed February 29, 2012. http://www.itfacts.biz/telecom-spending-to-reach-92391-bln-in-2008/11091

Jhally, Sut and Bill Livant. 1986. Watching as Working: The Valorization of Audience Consciousness. Journal of Communication 36 (3):124-143.

Jubas, Kaela. 2007. Conceptual Con/Fusion in Democratic Societies: Understandings and Limitations of ConsumerCitizenship. Journal of Consumer Culture 7 (2): 231-254.

Kjøsen, Atle Mikkola. 2010. An Accident of Value: A Marxist-Virilian Analysis of Digital Piracy. Master's thesis, University of Western Ontario. Accessed January 14, 2012. http://uwo.academia.edu/kjosen/Papers/387636/An_Accident_of_Value_A_Marxist-Virilian_Analysis_of_Digital_Piracy

Lazzarato, Maurizio. 1996. Immaterial Labor. In Radical Thought in Italy: A Potential Politics, edited by Paolo Virno and Michael Hardt, 132-146. Minneapolis: University of Minnesota Press.

Lukács, Georg. 1971. History and Class Consciousness: Studies in Marxist Dialectics. Cambridge, MA: MIT Press.

Marcuse, Herbert. 1964. One-Dimensional Man: Studies in the Ideology of Advanced Industrial Society. Boston: Beacon Press.

Marx, Karl. 1859. Preface: A Contribution to a Critique of Political Economy. Accessed December 18, 2011. http://www.marxists.org/archive/marx/works/1859/critique-pol-economy/preface.htm

Marx, Karl. 1967. Capital. Vol. 1. New York: International Publishers.

Marx, Karl. 1971. The Poverty of Philosophy. Moscow: Progress Publishers.

Marx, Karl. 1973, The Grundrisse. Trans. M. Nicolaus. New York: Penguin. Accessed December 12, 2011. http://www.marxists.org/archive/marx/works/1857/grundrisse/ch10.htm

Marx, Karl and Friedrich Engels. 1845. The German Ideology. Accessed December 14, 2011. http://www.marxists.org/archive/marx/works/1845/german-ideology/ch01b.htm

Marx, Karl and Friedrich Engels. 1848. Manifesto of the Communist Party. Accessed December 13, 2011 http://www.marxists.org/archive/marx/works/1848/communist-manifesto/ch01.htm

Mclnerny, Vivian. 2003. Presenting a New Ideology. The Clothing Line aims for Style and Quality Without Designer Prices. The Oregonian, April 29, C-1.

Mullaney, Tim 2009. Global Ad Spending to Fall in 2009, Forecasters Say. Bloomberg News. Accessed January 13, 2012. http://www.bloomberg.com/apps/news?pid=newsarchive\&sid=aZ2ysU0uRIYo\&refer=home

Negri, Antonio. 2006. Goodbye Mr. Socialism: In Conversation with Raf Valvola Scelsi. New York: Seven Stories Press.

Sklair, Leslie. 2001. The Transnational Capitalist Class. Malden, MA: Blackwell

CC: Creative Commons License, 2012. 
Smith, Tony (n.d.). The 'General Intellect' in the Grundrisse and Beyond. Accessed March 23, 2012. http://www.public.iastate.edu/ tonys/10\%20The\%20General\%20Intellect.pdf

Smythe, Dallas W. 1977. Communications: Blindspot of Western Marxism. Canadian Journal of Political and Social Theory 1 (3): $1-27$.

Smythe, Dallas W. 1981. On the Audience Commodity and Its Work. In Dependency Road: Communications, Capitalism, Consciousness, and Canada, 22-51. Norwood, NJ: Ablex.

Sussman, Gerald. 1997. Communications, Technology, and Politics in the Information Age. Thousand Oaks, CA: Sage.

Sussman, Gerald. 2011. Introduction: The Propaganda Society. In The Propaganda Society: Promotional Culture and Politics in Global Context, edited by Gerald Sussman, 1-21. New York: Peter Lang.

Terranova, Tiziana. 2000. Free Labor: Producing Culture for the Digital Economy. Social Text 18 (2): 33-58.

Tilford, Dave. 2000. Why Consumption Matters. Sierra Club. Accessed February 12, 2012. http://www.sierraclub.org/sustainable_consumption/tilford.asp

Virno, Paolo. 2001. General Intellect. Trans. Arianna Bove. Accessed January 18, 2012. http://www.generationonline.org/p/fpvirno10.htm

Watts, William L. Daily Foreign-Exchange Turnover Hits \$4 Trillion. Market Watch. Accessed January 22, 2012. http://www.marketwatch.com/story/daily-currency-trading-turnover-hits-4-trillion-2010-09-01

Wayne, Mike. 2003. Marxism and Media Studies. London: Pluto Press.

Williams, Raymond. 1973. Base and Superstructure in Marxist Cultural Theory. Accessed December 15, 2011. http://www.rlwclarke.net/courses/LITS3303/20082009/04CWilliamsBaseandSuperstructureinMarxistCulturalTheory.pdf

Wilson, Eric. 2009. Consumers of the World Unite. New York Times. Online edition, January 7.

Wood, Deborah J. 2008. Hanon McKendry Buys into Alternative Media Firm for Online Advertising Growth. Accessed January 22, 2012. http://www.rapidgrowthmedia.com/devnews/mndscpe1002.aspx

Žižek, Slavoj. 2009. First as Tragedy, Then as Farce. London: Verso.

Žižek, Slavoj. 2012. The Revolt of the Salaried Bourgeoisie. London Review of Books, 9-10. January 26.

Zwick, Detlev, Samuel K. Bonsu and Aron Darmody. 2008. Putting Consumers to Work: "Co-Creation" and New Marketing Govern-Mentality. Journal of Consumer Culture 8 (2): 163-196.

\section{About the Author}

Gerald Sussman

is Professor of Urban Studies and International Studies at Portland State University, where he teaches graduate courses in international development, political economy, political communication, and media studies. His latest book (as editor) is: The Propaganda Society: Promotional Culture and Politics in Global Context (Peter Lang, 2011). He is also the author of Branding Democracy: U.S. Regime Change in Post-Soviet Eastern Europe (Peter Lang, 2010), Global Electioneering: Campaign Consulting, Communications, and Corporate Financing (Rowman \& Littlefield, 2005), and Communication, Technology, and Politics in the Information Age (Sage, 1997), and editor of two other books. 